\title{
Perancangan Alat Produksi Tahu yang Higienis pada Industri Rumah Tangga
}

\author{
Anastasia L. Maukar*, Johan K. Runtuk, Andira \\ Jurusan Teknik Industri, Fakultas Teknik, Universitas Presiden, Jababeka Education Park Jalan Ki Hajar Dewantara, Bekasi,
} Jawa Barat 17550, Indonesia

\section{ARTICLE INFORMATION}

Article history:

Received: April 29, 2018

Revised: July 10, 2018

Accepted: July 23, 2018

\section{Kata Kunci:}

Higienis

Respon Teknis

Rancangan Alat Produksi

Tahu

Keywords:

Designing Tool

Hygiene

Technical Response

Tofu

*Corresponding Author

Anastasia L. Maukar

E-mail: almaukar@president.ac.id

\section{A B S T R A K}

Industri tahu umumnya didominasi oleh usaha skala kecil dan menengah dengan metode produksi yang tradisional. Di sisi lain, permintaan masyarakat akan produk tahu cukup tinggi, sehingga diperlukan upaya untuk meningkatkan proses pembuatan tahu. Penelitian ini bertujuan untuk menghasilkan rancangan alat produksi pembuatan tahu yang higienis yang dapat menyederhanakan tahapan proses pembuatan tahu pada industri rumah tangga. Berdasarkan hasil wawancara dengan tiga industri rumah tangga pembuatan tahu di sekitar Cikarang, kabupaten Bekasi, didapatkan 17 atribut keinginan dalam rancangan alat produksi. Berdasarkan hal tersebut, diperoleh empat respon teknis umum yang akan dikembangkan menjadi empat konsep desain. Setelah dilakukan seleksi konsep, maka diperoleh suatu rancangan alat produksi pembuatan tahu yang mampu menggabungkan proses pembuatan tahu, yaitu mulai dari tahapan proses memisahkannya dari ampas sampai dengan proses memotong tahu, dapat disatukan dalam satu rancangan alat tersebut. Jadi rancangan alat produksi ini menggabungkan enam tahapan proses produksi.

\section{A B S T R A C T}

Tofu industry dominates by small-scale business with traditional production methods. On the other hand, demand for tofu products is quite high, and it is needed to increase tofu production. This study discusses the making of hygiene tofu maker tools able to simplify the production process. Based on the results of interviews with three tofu home industries in Cikarang, Bekasi, 17 request attributes of making an assistive tool obtain. Based on this, four technical responses were collected and will be developed become four concept designs. After conducting concept selection, it is determined to plan for making a tool which can simplify the process of making tofu. That is, starting from the manufacturing process, which starts from the pulp to the process of making tofu, can be put together into one manufacture of the tool. Thus, designing this tool can integrate the six stages of the tofu production process.

This is an open access article under the CC-BY-NC-SA license.

\section{PENDAHULUAN}

Tahu merupakan makanan yang masih banyak dikonsumsi oleh masyarakat Indonesia, karena merupakan makanan bergizi dan sumber protein yang tinggi dengan harga terjangkau oleh hampir semua lapisan masyarakat [1], [2]. Saat ini produksi tahu masih banyak dipasok oleh industri tahu skala kecil dan menengah. Industri ini masih menggunakan metode tradisional, padahal 
permintaan tahu cukup tinggi dan daya beli masyarakat untuk produk ini relatif tinggi [3].

Jumlah permintaan tahu dapat dilihat dari ratarata konsumsi per minggu per kapita dalam dua tahun terakhir yaitu 2016 dan 2017, mencapai 1,51 dan 1,57 ons. Hal ini mengalami peningkatan ditinjau dari tahun 2013 dan 2014, dimana rata-rata konsumsi per minggu per kapita sebesar 1,36 dan 1.44 ons [4]. Berdasarkan data penelitian klaster industri kecil dan kerajinan di provinsi Jawa Barat pada tahun 2006, diketahui bahwa jumlah industri kecil pembuatan tahu dan tempe di kabupaten Bekasi adalah 13 buah [5].

Industri rumah tangga merupakan usaha kecil dan menengah yang masih memiliki banyak kekurangan seperti belum menggunakan teknologi yang dapat meningkatkan produksi, belum memperhatikan sistem pembuangan dan penanganan limbah, memiliki hambatan dalam permodalan untuk pengembangan usaha dan sebagainya [6]. Hal ini menyebabkan industri rumah tangga masih belum mampu berproduksi secara efisien.

Industri rumah tangga produk tahu secara tradisional dimulai dengan penggilingan kedelai yang sudah dikupas bersih dan kemudian dimasak hingga mendidih. Setelah adonan tahu masak, maka akan dilakukan penyaringan dan penggumpalan serta pencetakan. Tahu yang sudah mengeras di dalam cetakan, siap dipotong-potong. Untuk meningkatkan produksi tahu pada industri rumah tangga yang masih menggunakan cara-cara tradisional, maka perlu adanya suatu alat atau teknologi produksi yang dapat membantu mereka dalam meningkatkan jumlah produksi tahu, selain itu alat yang akan dirancang juga harus higienis dan aman bagi manusia. Higienitas sangat penting agar produk tahu tidak mudah basi dan berlendir, serta berasa asam [7].

Beberapa penelitian telah mengembangkan alat penyaringan tahu yang bertujuan untuk mengurangi keluhan pekerja pada proses penyaringan yang membutuhkan banyak energi [8], [9] dan untuk meningkatkan produktivitas dengan menggunakan mesin penyaringan [10], [11]. Penelitian lain yang berkaitan dengan penyaringan tahu adalah untuk mengurangi keluhan muskuloskeletal yang berdampak pada peningkatan produktivitas dengan metode Macroergonomic Analysis and Design (MEAD) [12] dan mengurangi keluhan pengguna dengan menggunakan QFD and antropometri [13].

Peningkatan produktivitas produksi tahu dapat dilakukan dengan cara melakukan desain ulang metode kerja [14], [15] maupun perancangan stasiun kerja yang lebih ergonomis [16]. Peningkatan produktivitas juga dapat dilakukan dengan cara desain ulang alat pemotong tahu [17], [18], dan [19] maupun alat bantu press [20], [21], dan [22] untuk mengurangi beban kerja pekerja.

Selain itu, untuk mengurangi cacat pada proses tahu, di rancang cetakan tahu dengan mempertimbangkan faktor biaya [23]. Penelitian lainnya yang berkaitan dengan ergonomis adalah berupa usulan pembuatan alat bantu pengangkatan sari kedelai dari tungku penyaringan [24]. Penelitian lainnya adalah perancangan alat pengepresan dan pemotongan tahu yang menyatukan proses pengepresan sekaligus proses pemotongan tahu yang ergonomis [25].

Salah satu kekurangan dalam industri rumah tangga adalah peningkatan produksi dengan mempertimbangkan faktor higienis. Penelitian sebelumnya lebih banyak melakukan desain pada salah satu proses dalam meningkatkan produktivitas dan kenyamanan kerja karyawan tanpa menyederhanakan proses pembuatan tahu. Penelitian ini mencoba melakukan pengembangan alat produksi pembuat tahu yang dapat meningkatkan produksi bagi industri rumah tangga dengan menyederhanakan proses pembuatan tahu dengan yang dimulai dari proses pemisahan dari ampas sampai dengan proses memotong tahu, sehingga proses penyaringan air tahu, pengepresan dan pembentukan tahu terintegrasi dalam satu alat ini dengan menggunakan metode perancangan dan pengembangan produk. Penggabungan proses ini dapat mempercepat proses produksi dan mengurangi kontak langsung pekerja dengan produk yang pada proses pemotongan sehingga dapat meningkatkan higienitas pada produk tahu

\section{METODE PENELITIAN}

Penelitian ini dilakukan di tiga industri rumah tangga di daerah bekasi. Tahapan penelitian 
mengacu pada konsep yang dikembangkan Ulrich dan Eppinger [26] dalam mengembangkan suatu produk. Tahapan penelitian tersebut terdiri dari observasi awal, identifikasi kebutuhan pelanggan, product introduction, pengembangan konsep produk, seleksi konsep dan pengujian konsep produk (Gambar 1).

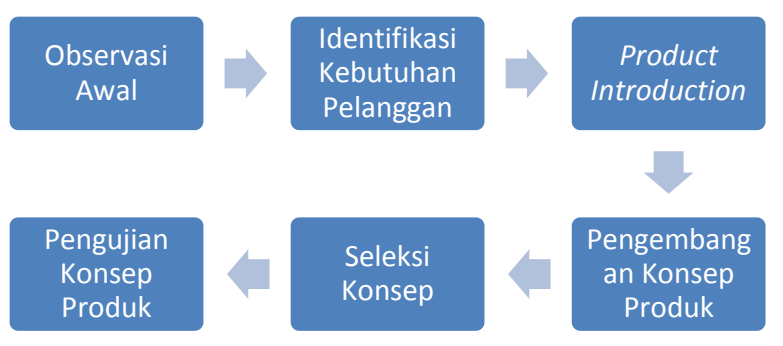

Gambar 1. Langkah-langkah penelitian

Observasi awal dilakukan pada salah satu industri rumah tangga pembuat tahu di daerah Cikarang, kabupaten Bekasi untuk mengetahui kebutuhan pengguna alat produksi pembuat tahu dan untuk menciptakan ide-ide kreatif dan inovatif bagi rancangan produk alat produksi pembuat tahu, langkah selanjutnya adalah identifikasi pelanggan, yaitu sejumlah tiga buah industri di daerah Cikarang. Kebutuhan pelanggan adalah keinginan konsumen untuk mendapatkan manfaat khusus suatu produk atau layanan, apakah itu fungsional atau emosional. Proses pengambilan keputusan terdiri dari lima langkah konsumen, meliputi spesifikasi kebutuhan, pencarian informasi dan pengolahan, identifikasi dan evaluasi alternatif, keputusan pembelian dan perilaku pasca pembelian.

Setelah mengetahui kebutuhan industri rumah tangga pembuat tahu, langkah selanjutnya adalah memperkenalkan produk alat produksi pembuat tahu (product introduction). Dalam tahapan ini akan ditentukan pula spesifikasi produk seperti dimensi, material yang akan digunakan, fungsi produk, kelebihan-kelebihan keunggulan produk, dan lain-lainya. Pada tahap pengembangan konsep produk akan dijelaskan secara teknis mengenai bagaimana produk mampu memenuhi kebutuhan pelanggan dan melampaui harapan pelanggan.

Seleksi konsep merupakan metode untuk memformulasikan suatu konsep yang akan dikembangkan dan proses ini membutuhkan concept scoring dan concept screening. Pada tahapan pengujian konsep produk dilakukan uji kualitas dan ketahanan dari rancangan produk yang akan dibuat. Rancangan produk juga akan dipresentasikan ke pengguna untuk mendapatkan masukan untuk peningkatan kualitas produk yang dirancang. Pada tahapan ini, dilakukan dengan mendatangi industri rumah tangga pembuat tahu di daerah Cikarang sejumlah tiga buah. Pengguna dalam hal ini adalah pekerja pada industri tersebut, masing-masing dua pekerja per industri rumah tangga.

\section{HASIL DAN PEMBAHASAN}

\section{Observasi Awal}

Hasil observasi awal pada salah satu industri rumah tangga pembuat tahu di Kabupaten Bekasi, dapat diketahui bahwa proses pembuatan tahu saat ini banyak mengalami kesulitan. Saat ini proses pembuatan tahu, pada umumnya menggunakan alat terpisah dalam setiap tahapan sehingga membutuhkan waktu proses yang cukup lama serta membutuhkan lebih banyak ruang untuk melakukan tahapantahapan proses tersebut. Selain itu proses pembuatan tahu pada industri rumah tangga masih kurang higienis. Secara umum proses pembuatan tahu adalah sebagai berikut:

1. Membersihkan kedelai

2. Merendam kacang

3. Menggiling kedelai

4. Merebus hasil gilingan kedelai

5. Memisahkannya dari ampas

6. Memadatkan kedelai

7. Menekan tahu

8. Menyaring air sisa tahu

9. Mencetak tahu

10. Memotong tahu

11. Merebus ulang

\section{Identifikasi Kebutuhan Pelanggan}

Berdasarkan hasil wawancara dengan enam pekerja dari tiga industri rumah tangga pembuat tahu, maka didapatkan daftar kebutuhan pelanggan yang berupa 17 atribut, sebagai berikut:

1. Harga produk terjangkau

2. Bahan yang digunakan tahan lama 
3. Proses produksi membutuhkan kekuatan kecil

4. Pemeliharaan produk cukup mudah

5. Bahan yang digunakan adalah aman untuk makanan

6. Pergerakan produk itu mudah

7. Produk menggunakan daya listrik kecil

8. Produk dapat mempercepat proses produksi sehingga dapat meningkatkan produktivitas

9. Produk mudah ditangani

10.Biaya perawatannya murah

11.Produk ini dapat digunakan untuk produksi massal

12.Produk ini mudah digunakan

13.Produk ini mudah diangkut/dipindahkan

14.Produk ini mudah dan aman untuk diperbaiki dan diatur

15.Aman dan mudah digunakan oleh hampir semua orang

16. Produk ini ramah lingkungan

17.Produk ini dapat menjamin higienitas tahu yang dihasilkan

\section{Product Introduction}

Berdasarkan keinginan pelanggan dan juga hasil observasi lapangan ke industri rumah tangga pembuat tahu, maka selanjutnya akan dikembangkan spesifikasi teknis untuk menjawab keinginan pelanggan tersebut.

Berdasarkan 17 kebutuhan pelanggan, maka ditetapkan beberapa spesifikasi teknis umum, antara lain:

1. Penggunaan material kayu dan bahan lain yang mudah didapatkan dan murah

2. Penggabungan proses produksi dan proses yang bersih.

3. Desain alat produksi yang mudah dan nyaman dioperasikan

4. Penggunaan roda dan mudah dipindahkan yang dapat menyederhanakan beberapa proses pembuatan tahu.

Dengan memperhatikan keempat spesifikasi teknis umum di atas, maka ditetapkan bahwa fokus utama perbaikan pada proses pembuatan tahu adalah agar menjadi lebih cepat dan mudah serta lebih higienis. Dari hasil wawancara ditetapkan bahwa alat produksi pembuatan tahu yang dirancang adalah cetakan tahu yang dapat menyederhanakan proses menjadi satu kesatu- an. Selain itu rancangan alat dapat menyaring air tahu, menekan dan jika tahu telah mengeras dapat langsung dipotong-potong sehingga mampu mempercepat proses produksi tahu dan meningkatkan higienitas.

Alat produksi yang akan dikembangkan ini akan menggabungkan tahapan proses memisahkannya dari ampas (proses nomor 5) sampai dengan proses memotong tahu (proses no. 10) serta dapat meningkatkan higienitas dari proses pembuatan tahu, karena penekanan dan penyaringannya dilakukan secara bersamaan pada alat yang akan dirancang. Selain itu dengan penyederhanaan proses menjadi satu kesatuan.

Sedangkan keunggulan dari produk alat produksi yang akan dikembangkan adalah sebagai berikut:

1. Menggabungkan proses pembuatan tahu, yaitu ada 6 proses pembuatan tahu yang disatukan

2. Mengurangi perpindahan pekerja dari satu tempat kerja ke tempat kerja berikutnya. Alat produksi ini hanya satu tempat kerja, sehingga pergerakan pekerja dari satu tempat kerja ke tempat kerja lainnya dapat dikurangi.

3. Sangat mendukung industri rumah tangga dan usaha kecil (produksi pembuat tahu)

4. Mudah digunakan. Semua prosedur dalam membuat tahu benar-benar mudah oleh produk ini seperti membentuk, pola, air bocor, menekan, dll.

5. Ergonomis. Produk ini dapat dioperasikan hanya oleh satu operator.

6. Hemat listrik. Produk ini tidak memerlukan energi listrik sehingga dapat menghemat biaya listrik.

7. Ramah Lingkungan. Tidak ada bahan bakar yang diperlukan untuk mengoperasikan produk ini, sehingga tidak akan ada limbah seperti asap atau bahan kimia yang dihasilkan.

8. Inovasi: dalam menyederhanakan proses pembuatan tahu.

\section{Pengembangan Konsep}

Pada tahap pengembangan konsep, dilakukan penentuan teknis secara rinci yang berkaitan 
tentang bagaimana produk akan memuaskan kebutuhan pelanggan dan melampaui harapan pelanggan. Berbagai masalah yang mungkin muncul saat pengembangan konsep ini juga dikaji pada tahap ini. Misalnya: bahan baku/material, pengganti produk, respon pasar, konsumsi waktu, investasi mahal, dan sebagainya (Gambar 2, Gambar 3, Gambar 4, dan Gambar 5)

Selanjutnya dilakukan penelitian dengan mencari dari internet mengenai kemungkinan sistem yang akan diterapkan, bahan baku yang dapat memenuhi spesifikasi pelanggan, pendapat pelanggan tentang produk pesaing, perilaku pembelian, dan interval harga. Selanjutnya dilakukan survey ke calon pelanggan atau pembeli, yaitu dengan mengunjungi beberapa industri rumah tangga tahu di sekitar Kabupaten Bekasi.

\begin{tabular}{|c|c|c|c|}
\hline & 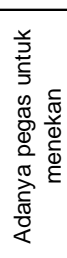 & 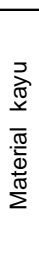 & 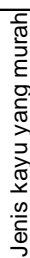 \\
\hline Tahan lama (durable) & & $x$ & \\
\hline Mudah dioperasikan (easy to use) & $x$ & & \\
\hline Membutuhkan daya tekan kecil & $x$ & & \\
\hline Efisien & $x$ & & \\
\hline Dapat menyederhanakan proses & $x$ & & \\
\hline Harga terjangkau (affordable) & & $x$ & $x$ \\
\hline
\end{tabular}

Gambar 2. Metrik dari konsep produk 1

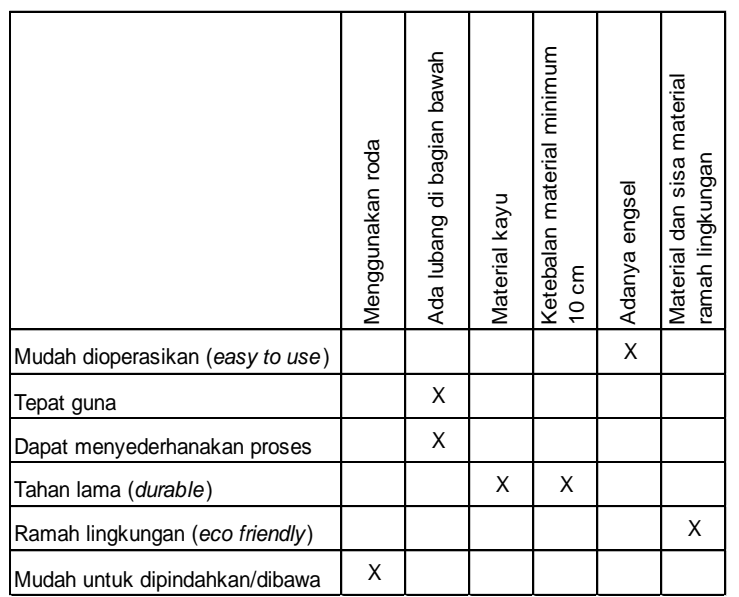

Gambar 3. Metrik dari konsep produk 2

\begin{tabular}{|c|c|c|c|c|c|}
\hline & 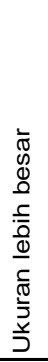 & 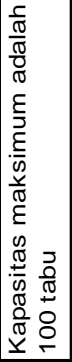 & 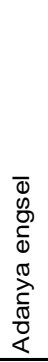 & 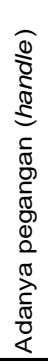 & 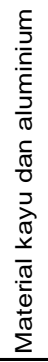 \\
\hline Produktivitas tinggi & $x$ & $x$ & & & \\
\hline Mudah dioperasikan (easy to use) & & & $x$ & & \\
\hline Aman bagi makanan & & & & & $X$ \\
\hline Mudah dipegang (easy to handle) & & & & $x$ & \\
\hline $\begin{array}{l}\text { Dapat digunakan untuk mass } \\
\text { production }\end{array}$ & & $X$ & & & \\
\hline
\end{tabular}

Gambar 4. metrik dari konsep produk 3

\begin{tabular}{|c|c|c|c|c|c|c|}
\hline & 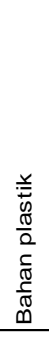 & 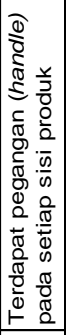 & 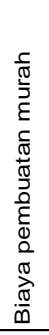 & 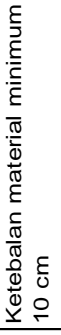 & 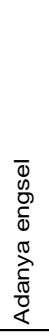 & 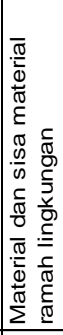 \\
\hline Harga terjangkau (affordable) & $x$ & & $x$ & & & \\
\hline Tahan lama (durable) & & & & $x$ & & \\
\hline Mudah dioperasikan (easy to use) & & $x$ & & & $x$ & \\
\hline Mudah dipegang (easy to handle) & & $x$ & & & & \\
\hline Biaya perawatan murah & $x$ & & & & & \\
\hline Ramah lingkungan (eco friendly) & & & & & & $x$ \\
\hline
\end{tabular}

Gambar 5. Metrik dari konsep produk 4

Konsep dasar dari produk ini adalah penyederhanaan proses produksi tahu. Ini menggabungkan beberapa bagian yang memiliki fungsi berbeda menjadi satu produk saja dan proses produksi yang bersih dengan mengurangi kontak tangan pekerja dengan produk. Pengguna dapat meminimalkan ruang kerja mereka dengan menggunakan bagian demi bagian secara bergantian, dan jika pengguna sudah menyelesaikan pekerjaan mereka, alat dapat ditumpuk, sehingga dapat menghemat ruang kerja.

Selanjutnya dikembangkan beberapa konsep produk yang diterjemahkan dalam gambar 
tangan (sketsa). Detail produk sudah dijelaskan dalam spesifikasi produk. Alat ini dapat dikembangkan menjadi produk yang cocok dengan setiap orang dengan memberikan atau menghilangkan beberapa bagian, sehingga produk tersebut cocok dengan mereka.

Konsep produk yang berhasil dibuat ada empat seperti terlihat pada Gambar 6. Pada konsep 1, untuk mengurangi gesekan antar bagian, maka dilakukan penambahan beberapa pegas di setiap sudut. Dioperasikan secara bergantian, bagian demi bagian, dan mengubah bagian yang akan digunakan secara manual, Dimensi produk (pxIxt) adalah $1.06 \times 0.58 \times 0.41 \mathrm{~cm}$ dengan material kayu balsa (tahan air). Sedangkan konsep 2 adalah berkaitan dengan pertimbangan jumlah produksi/output dari tahu itu sendiri. Jika hasil rebusan gilingan kedelai langsung disaring, mungkin beberapa rebusan gilingan kedelai akan terlalu banyak tersaring. Maka perlu ada jeda, yaitu perlu memberi waktu untuk mengendapkan tahu dengan menambahkan lubang-lubang knobbed. Dimensi produk (pxIxt) adalah $1.06 \mathrm{x}$ $0.58 \times 0.41 \mathrm{~cm}$ dan material kayu balsa (tahan air).

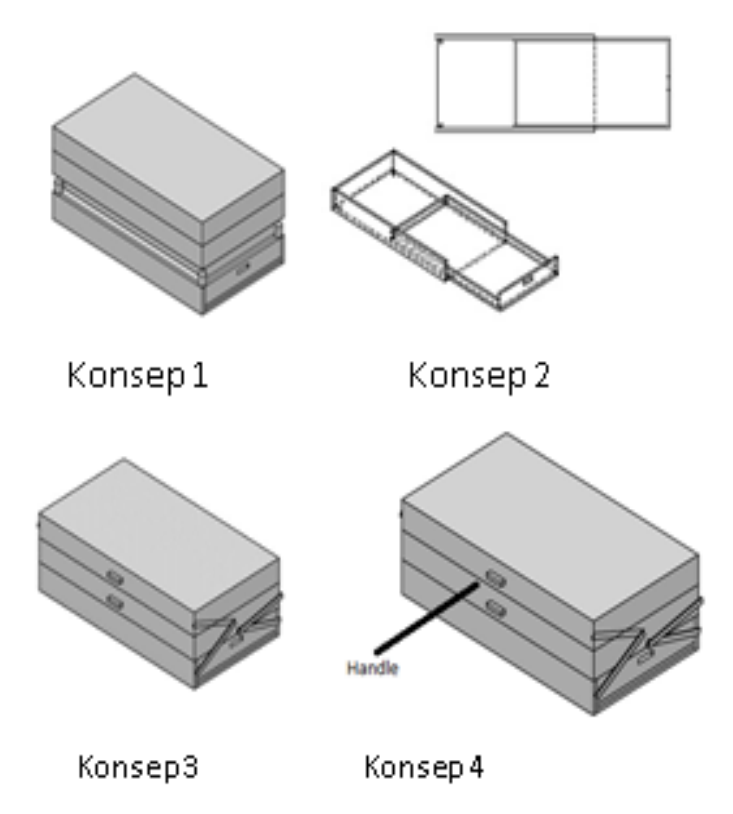

Gambar 6. Konsep produk

Konsep ketiga tidak ada fitur tambahan, tetapi ada perubahan bahan produk. Dalam hal ini dilakukan pertimbangan untuk membuat produk ini lebih tahan lama, karena kayu dapat dihancurkan dalam waktu singkat sehingga diusulkan untuk mencoba membuatnya dari aluminium. . Dimensi produk (pxlxt) adalah $1.06 \mathrm{x}$ $0.58 \times 0.41 \mathrm{~cm}$ dan material kayu balsa (tahan air). Konsep keempat, tidak ada fitur tambahan, tetapi hanya ditambahkan pegangan yang mempermudah operator untuk mengoperasikan produk ini. Ini juga untuk meminimalkan terjadinya kecelakaan seperti tergelincir. Dimensi produk (pxlxt) adalah $1.06 \times 0.58 \times 0.41 \mathrm{~cm}$ dan material kayu balsa.

\section{Seleksi Konsep}

Dalam penelitian ini, di buat empat buah konsep produk alat produksi, dan dilakukan proses skoring (Tabel 1) dan screening. Dalam hal ini ada 14 kriteria yang akan digunakan dalam proses penyaringan konsep. Proses penyaringan dan skoring sangat membantu, karena jauh lebih mudah untuk membandingkan dua opsi atau pilihan daripada mengalokasikan skor mandiri ke satu pilihan.Dari hasil seleksi didapatkan bahwa gabungan konsep 1 dan konsep 3 yang akan dikembangkan lebih lanjut.

Setelah penyaringan dan skoring konsep maka langkah selanjutnya adalah pembentukan House of Quality (HOQ). HOQ dibentuk dari ke-14 kriteria yang telah ditetapkan sebelumnya dan menunjukkan hubungan kriteria tersebut dengan functional requirements serta korelasi antar functional requirements seperti yang terlihat pada Gambar 7.

Adapun gambaran arsitektur dari konsep produk yang akan dikembangkan dapat dilihat pada Gambar 8. Sedangkan Gambar 9 menunjukkan material pembuatan produk dan keamanannya. Keamanan dalam hal ini, termasuk aman bagi pengguna (pekerja) dan bagi konsumen sehingga material juga harus dalam kategori food grade. Material utamanya adalah kayu balsa (Ochroma pyramidale), karena harga material kayu murah dan ramah lingkungan daripada menggunakan aluminium atau plastik. Alasan lainnya adalah bahan kayu ini cukup kuat, mudah didapatkan, dan banyak digunakan juga untuk material pembuatan furniture, material seni dan lainnya [27]. 
Tabel 1. Skoring konsep

\begin{tabular}{|c|c|c|c|c|c|c|c|}
\hline \multirow{2}{*}{ Skoring } & & \multicolumn{6}{|c|}{ Konsep } \\
\hline & & \multicolumn{2}{|c|}{2} & \multicolumn{2}{|c|}{4} & \multicolumn{2}{|c|}{$1 \& 3$} \\
\hline Kriteria & Bobot & Rating & $\begin{array}{l}\text { Bobot } x \\
\text { Skor }\end{array}$ & Rating & $\begin{array}{l}\text { Bobot x } \\
\text { Skor }\end{array}$ & Rating & $\begin{array}{l}\text { Bobot } x \\
\text { Skor }\end{array}$ \\
\hline harga terjangkau & $12 \%$ & 3 & 0,36 & 2 & 0,24 & 3 & 0,36 \\
\hline Kokoh & $7 \%$ & 3 & 0,21 & 2 & 0,14 & 4 & 0,24 \\
\hline Efisien & $7 \%$ & 3 & 0,21 & 3 & 0,21 & 3 & 0,21 \\
\hline Tahan lama (Durable) & $7 \%$ & 3 & 0,21 & 4 & 0,28 & 3 & 0,21 \\
\hline Mudah dipindahkan & $5 \%$ & 3 & 0,15 & 3 & 0,15 & 3 & 0,15 \\
\hline Hemat energi & $5 \%$ & 3 & 0,15 & 3 & 0,15 & 3 & 0,15 \\
\hline Hemat listrik & $5 \%$ & 3 & 0,15 & 3 & 0,15 & 3 & 0,15 \\
\hline Ramah lingkungan & $5 \%$ & 3 & 0,15 & 3 & 0,15 & 3 & 0,15 \\
\hline $\begin{array}{l}\text { Mudah untuk } \\
\text { dioperasikan }\end{array}$ & $12 \%$ & 3 & 0,36 & 3 & 0,36 & 3 & 0,36 \\
\hline $\begin{array}{l}\text { Mudah dalam } \\
\text { perbaikan }\end{array}$ & $5 \%$ & 3 & 0,15 & 3 & 0,15 & 2 & 0,10 \\
\hline Tepat guna & $12 \%$ & 3 & 0,36 & 3 & 0,36 & 3 & 0,36 \\
\hline Aman bagi pengguna & $8 \%$ & 3 & 0,24 & 3 & 0,24 & 3 & 0,24 \\
\hline Material aman & $5 \%$ & 3 & 0,15 & 4 & 0,20 & 3 & 0,15 \\
\hline $\begin{array}{l}\text { Membutuhkan ruang } \\
\text { kecil }\end{array}$ & $5 \%$ & 3 & 0,15 & 3 & 0,15 & 3 & 015 \\
\hline Total Skor & & \multicolumn{2}{|c|}{3} & \multicolumn{2}{|c|}{2,93} & \multicolumn{2}{|c|}{3,02} \\
\hline Rangking & & \multicolumn{2}{|c|}{2} & \multicolumn{2}{|c|}{3} & \multicolumn{2}{|c|}{1} \\
\hline Lanjut? & & \multicolumn{2}{|c|}{ Tidak } & \multicolumn{2}{|c|}{ Tidak } & \multicolumn{2}{|c|}{$\mathrm{Ya}$} \\
\hline
\end{tabular}

Sebagai bahan penyaring, digunakan kain blacu putih. Blacu adalah kain yang termurah dan ramah lingkungan. Karena proses pembuatan blacu ini sangat mudah dan tidak mengandung bahan kimia. Untuk presser, dipertimbangkan bahwa akan mudah digunakan untuk hampir semua orang, baik pria, wanita, orang tua, dan orang muda. Cara menggunakannya hanya dengan menarik knop/tombol yang aman. Yang terakhir adalah alat pemotong berbahan aluminium yang food grade dan dapat didaur ulang lagi.

\section{Pengujian Konsep}

Pengujian konsep adalah langkah untuk membuktikan kualitas dan kelayakan produk berdasarkan kelompok lain, yaitu pelanggan. Proses ini dilakukan dengan mempresentasikan konsep produk terpilih kepada calon pembeli/pemakai yaitu pada pekerja atau pemilik industri rumah tangga tahu untuk mendapatkan masukan-masukan bagi perbaikan dalam pengembangan produk. Dari beberapa hasil presentasi tersebut, maka perlu mempertimbangkan beberapa perbaikan yaitu:

1. Penambahan roda dibagian bawah produk untuk mempermudah pergerakan produk.

2. Penambahan pegangan untuk memudahkan transisi untuk setiap proses.

3. Penggunaan material kayu dan aluminium yang lebih murah karena lebih mudah dalam proses pembuatan alat produksi. Meskipun plastik lebih murah, namun proses pembuatan produk dengan material plastik jauh lebih sulit.

4. Pembuatan lubang dibagian bawah produk untuk mempercepat proses penyaringan air. 


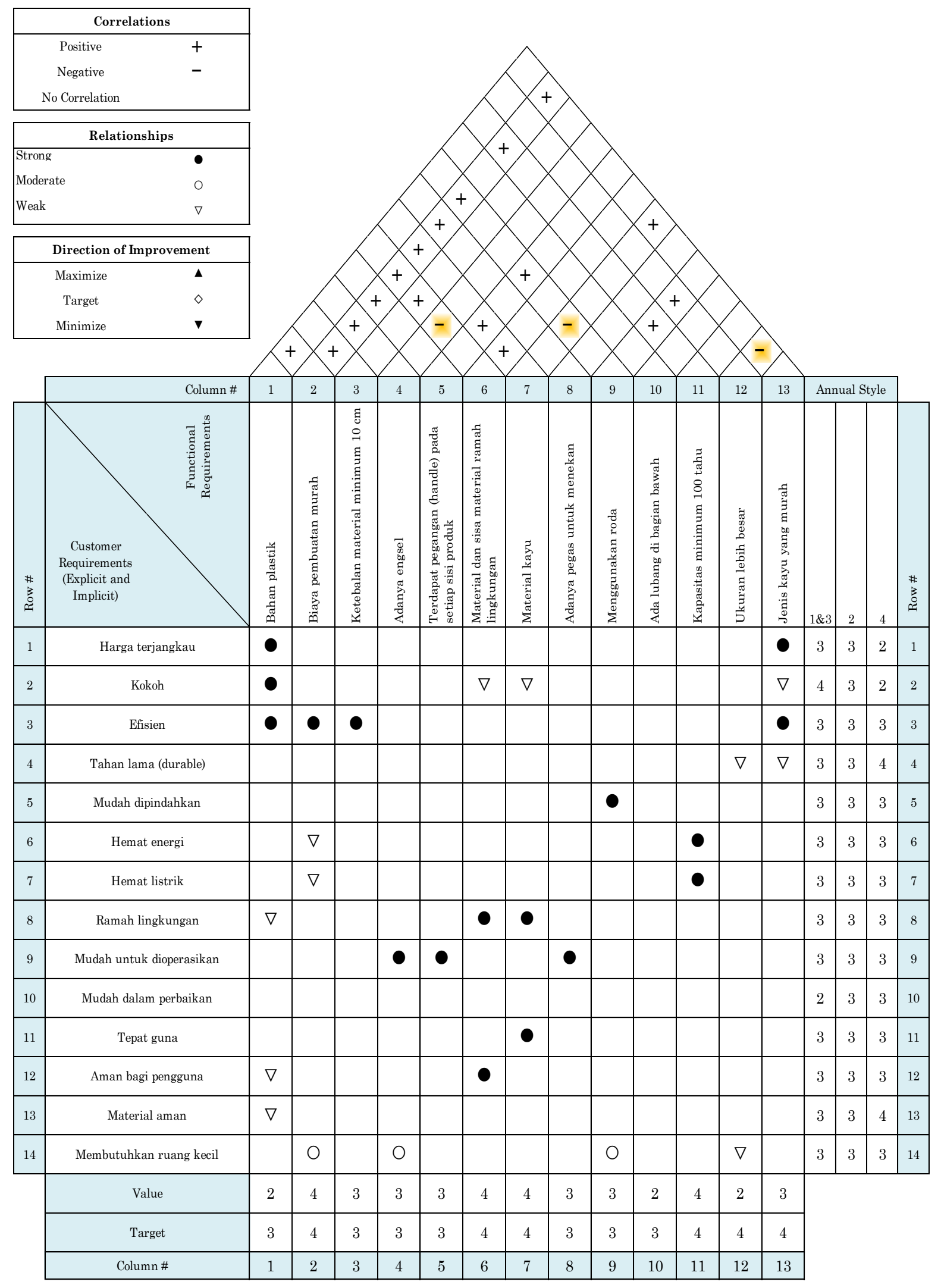

Gambar 7 House of quality 
5. Penggunaan menggunakan kain sintetis yang dapat diganti secara manual sehingga mempermudah dalam proses pemeliharaan.

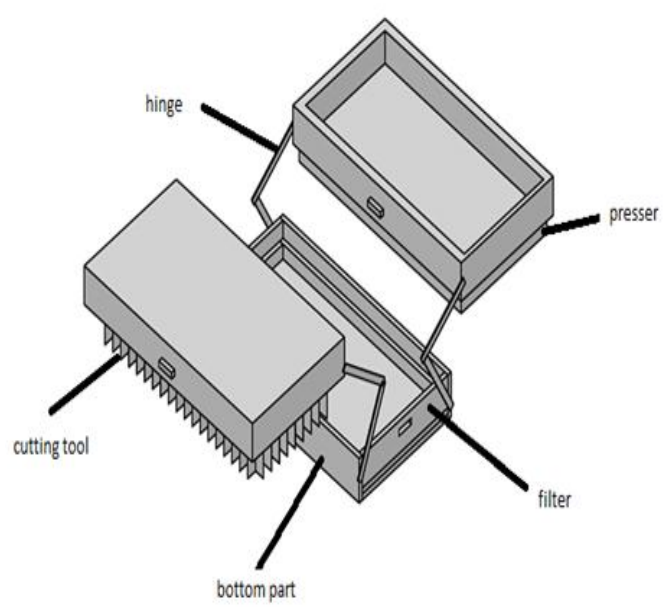

Gambar 8. Arsitektur alat produksi proses pembuatan tahu

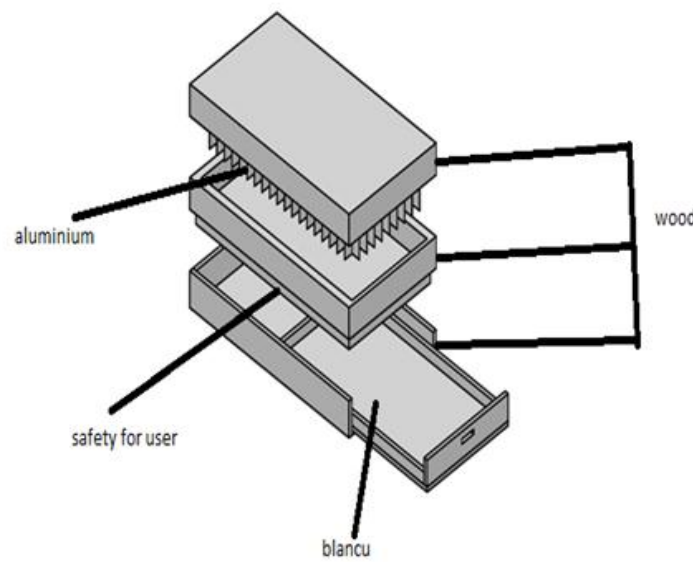

Gambar 9. Material untuk pembuatan produk

\section{Hasil Rancangan}

Setelah melalui tahap pengujian konsep, rancangan alat produksi disempurnakan. Hasil akhir dari rancangan tersebut dapat dilihat pada Gambar Teknis per bagian dari produk secara lengkap yang disajikan pada Gambar 10, Gambar 11, Gambar 12, dan Gambar 13 sedangkan cara kerja secara umum dapat dilihat pada Gambar 14. Selanjutnya penelitian ini telah berhasil dibuat prototype produk seperti terlihat pada Gambar 15. Sedangkan penjelasan tentang fungsi masing-masing bagian dapat dilihat pada Gambar 16.

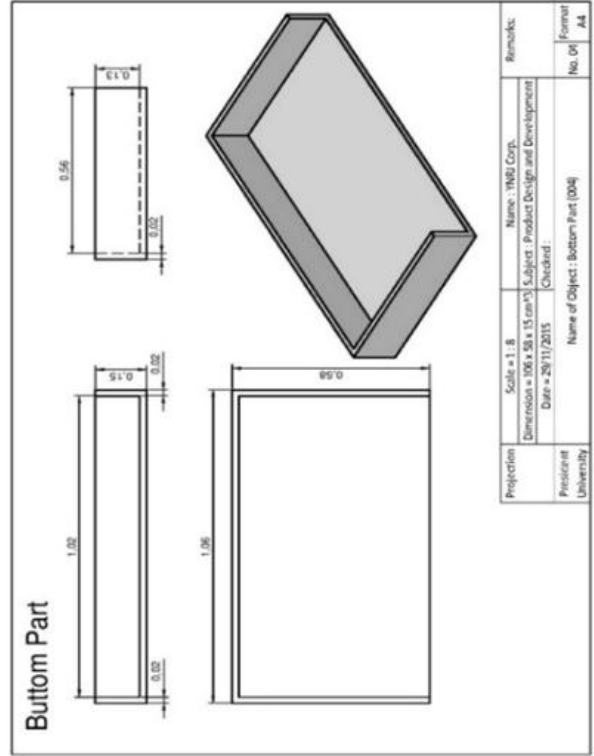

Gambar 10. Bagian bawah dari produk

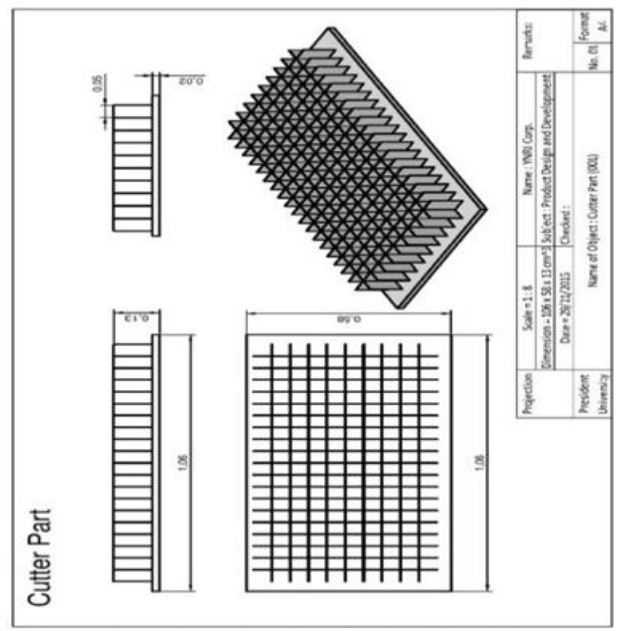

Gambar 11. Bagian cutter/pemotong

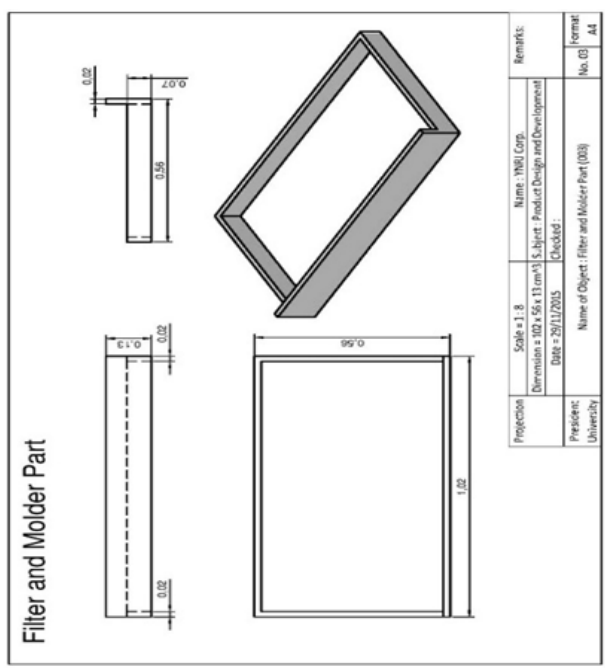

Gambar 12. Bagian filter dan molder 


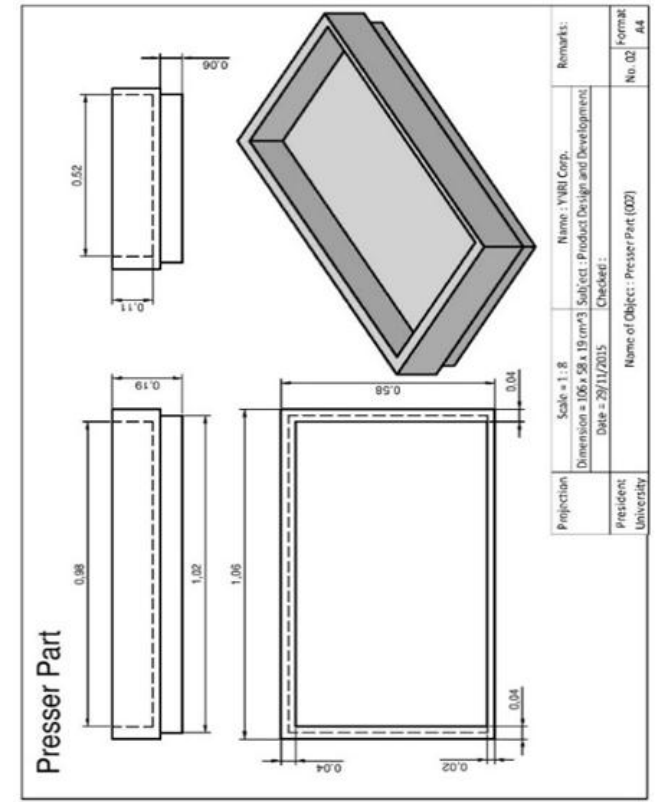

Gambar 13. Bagian presser

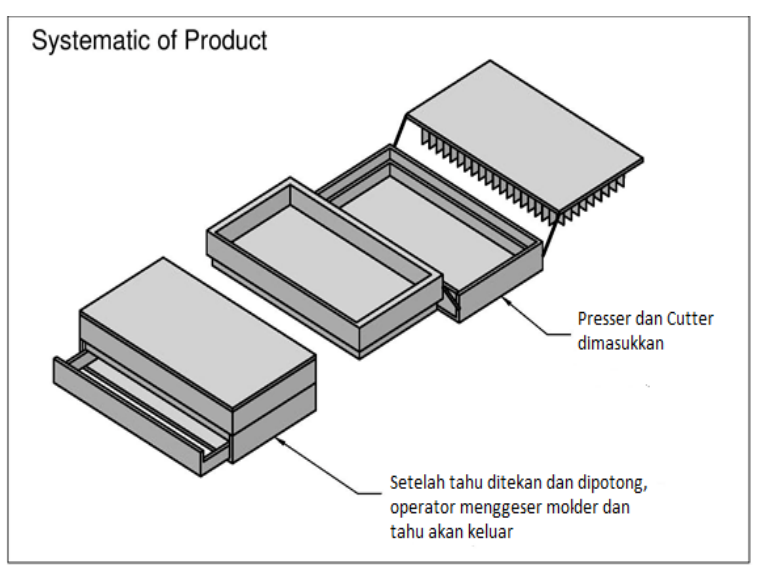

Gambar 14. Cara kerja

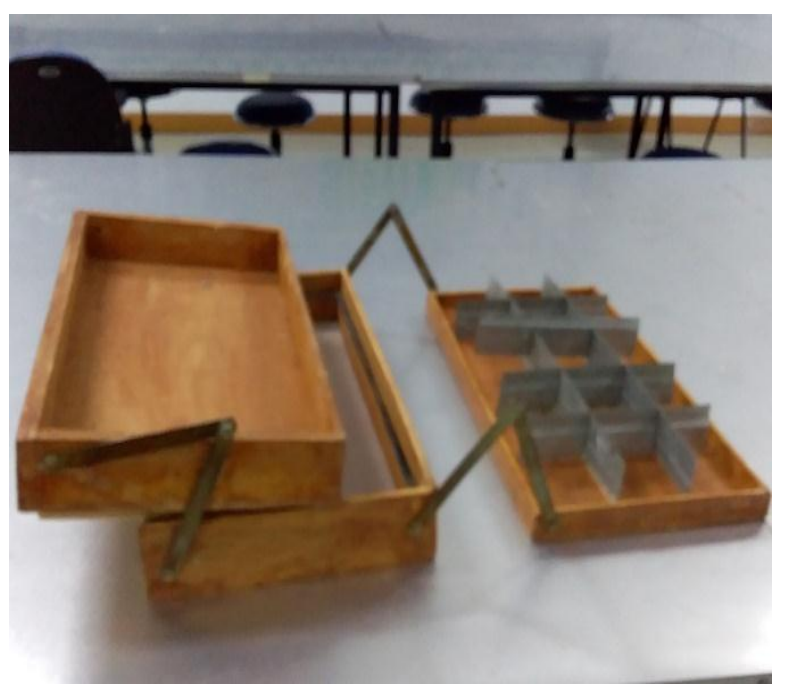

Gambar 15. Prototipe produk

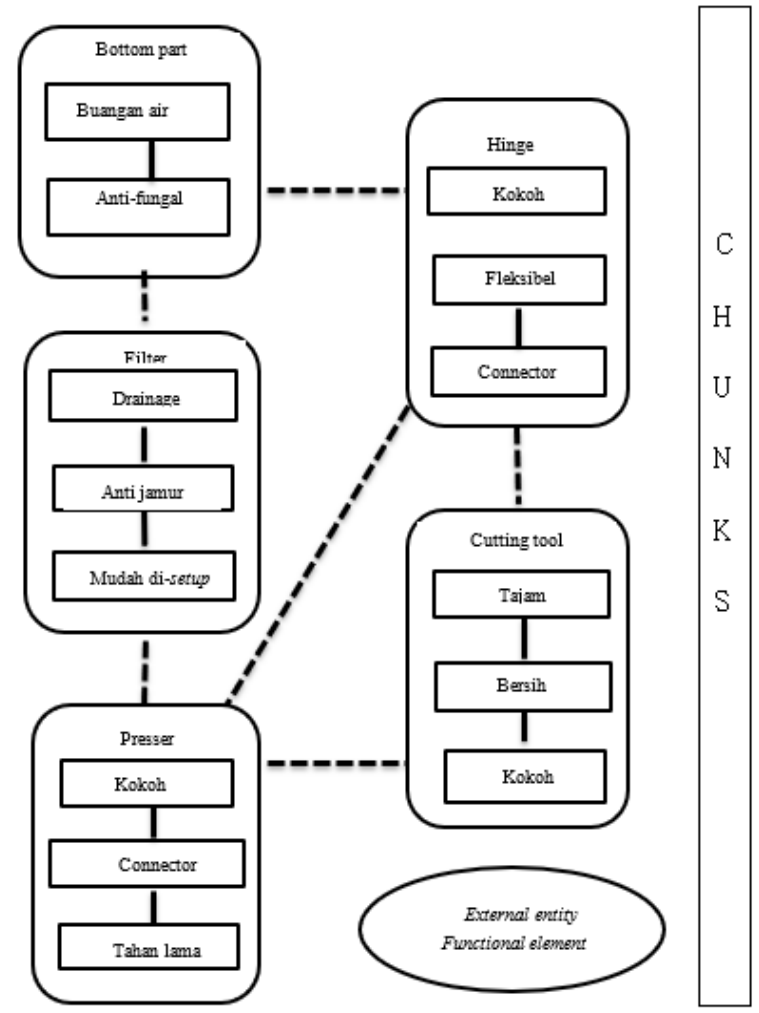

Gambar 16. Chunks dan elemen fungsional dari alat produksi secara rinci

Produk alat produksi ini berhasil menggabungkan beberapa proses yaitu dari mulai memadatkan kedelai, menekan tahu, menyaring air sisa tahu, mencetak tahu sampai memotong tahu, sehingga dapat menghemat waktu proses produksi. Selain itu, pekerja tidak menyentuh langsung tahu pada proses pemotongan sehingga dapat meningkatkan higienitas pada produk tahu. Pekerja tidak perlu berpindah tempat kerja dari satu proses ke proses berikutnya. Selain itu, beberapa keuntungan dari pembuatan alat produksi ini adalah proses pembuatannya cukup mudah, serta menggunakan material yang terdapat di pasaran.

\section{KESIMPULAN}

Dari penelitian ini, dihasilkan suatu rancangan alat produksi proses pembuatan tahu yang dapat meningkatkan output produksi dan higienitas proses. Hal tersebut dapat dicapai oleh penyederhanaan proses pembuatan tahu yaitu mulai dari tahapan proses memisahkannya dari ampas (proses nomor 5) sampai dengan proses memotong tahu (proses no. 10) yang disatukan dalam satu rancangan alat tersebut serta pekerja tidak menyentuh secara langsung produk tahu. 
Penyederhanaan proses juga dapat mengurangi waktu proses pembuatan, terutama waktu perpindahan antar proses. Selain itu higienitas dari proses pembuatan tahu juga dapat dicapai, karena penekanan dan penyaringannya dilakukan secara bersamaan.

Untuk penelitian lebih lanjut, perlu adanya pengembangan produk ini dengan mempertimbangkan aspek ergonomis. Selain itu perlu dilakukan penentuan cara menyediakan bentuk varietas pemotong tahu pemilihan material yang dipakai dengan lebih rinci, terutama material yang tahan air, karena proses produksi tahu membutuhkan air sehingga produk akan tersentuh dengan air secara terus-menerus. Jadi bahan dasarnya harus tahan air agar produknya tahan lama.

\section{DAFTAR PUSTAKA}

[1] F. R. Tandian, "Pengelolaan dan Pengembangan Usaha Produksi Tahu pada Perusahaan Keluarga Ud. pabrik Tahu Saudara di Surabaya," Agora, vol. 1, no. 2, pp. 911-916, 2013, available at: http://publication.petra.ac.id/index.php/ma najemen-bisnis/article/view/431.

[2] W. Trusajia, P. Ajidarmab, and D. Iriantob, "SME's Technological Readiness to Fulfill the Tofu Product Standard (SNI 01-31421998)," Int. J. Appl. Sci. Eng., vol. 15, no. 2, pp. 113-118, 2018, available at: http://ir.lib.cyut.edu.tw:8080/bitstream/310 901800/35706/1/4_S-ICES-IJASE-2018003.pdf.

[3] S. . Hara, R. M. Kumaat, P. A. Pangemanan, and M. L. Sondakh, "Profil Industri Rumah Tangga Tahu Tempe ' $X$ ' di Kelurahan Bahu Kecamatan Malalayang," AGRI-SOSIOEKONOMI, vol. 13, no. 2A, p. 107, Aug. 2017, doi: 10.35791/agrsosek.13.2A.2017.16893.

[4] Badan Pusat Statistik, "Konsumsi tempe dan tahu per kapita dalam seminggu," 2018, available at: https://lokadata.beritagar.id/chart/preview/ konsumsi-tempe-dan-tahu-per-kapitadalam-seminggu-1522845039.

[5] Y. Hendrani, H. Djajadikerta, and U. Santoso, "Klaster Industri Kecil dan Kerajinan Rumah Tangga di Jawa Barat," Parahyangan Catholic University, 2009, available at: http://journal.unpar.ac.id/index.php/Sosial/ article/view/25.

[6] T. A. Kusumastuti, "Analisis manfaat dan biaya sosial limbah industri tahu dan limbah peternakan di daerah pedesaan
(Benefit and Social Cost Analysis of Tofu Industry and Livestock Waste Product in Rural Area)," Mns. dan Lingkung., vol. 12, no. I, pp. 1-12, 2005, available at: https://journal.ugm.ac.id/JML/article/view/ 18629.

[7] F. Rahmawati, "Materi Kegiatan: Teknologi Proses Pengolahan Tahu dan Pemanfaatan Limbahnya," Tanjung Enim, 2013, available at: http://staffnew.uny.ac.id/upload/13229604 8/pengabdian/teknologi-prosespengolahan-tahu-dan-pemanfaatanlimbahnya.pdf.

[8] J. Mulyana and W. Santosa, L M Hadi, \& Prasetya, "Perancangan Alat Penyaringan dalam Proses Pembuatan Tahu," J. Ilm. Tek. Ind., vol. 12, no. 1, pp. 21-30, 2013, available

at: http://staffnew.uny.ac.id/upload/13229604 8/pengabdian/teknologi-prosespengolahan-tahu-dan-pemanfaatanlimbahnya.pdf.

[9] L. D. Indirasari and S. Rahayuningsih, "Perancangan Alat Penyaring Tahu secara Ergonomis," in Seminar NAsional dan Gelar Produksi, 2017, pp. 12191229, available at: http://researchreport.umm.ac.id/index.php/researchreport/article/view/1496.

[10] A. Ardiawan and D. A. Walujo, "Perancangan Mesin Penyaringan dalam Proses Pembuatan Tahu Guna Meningkatkan Hasil Produktivitas dalam Skala Home Industry," WAKTU, vol. 14, no. 2, pp. 39-42, 2016, available at: http://jurnal.unipasby.ac.id/index.php/wakt u/article/view/133.

[11] A. G. Fauzan and S. T. Ratnanto Fitriadi, "Perancangan Alat Penyaring Otomatis Sari Pati Kedelai pada Pembuatan Tahu untuk mengurangi Waktu Proses dengan Metode Reverse Engineering (Studi Kasus: Rumah Produksi Tahu APU Klaten)," Skripsi. Solo: Fakultas Teknik, Universitas Muhammadiyah Surakarta, 2017, available at: http://eprints.ums.ac.id/49514/.

[12] A. Haripurna and H. Purnomo, "Desain Perancangan Alat Penyaring Dalam Proses Pembuatan Tahu Dengan Metode Macro Ergonomic Analysis and Design (MEAD)," J. IIm. Tek. Ind., vol. 16, no. 1, p. 22, Jul. 2017, doi: 10.23917/jiti.v16i1.3845.

[13] R. R. P. Zen and E. Suparti, "Perancangan Alat Penyaring Tahu Dengan Pendekatan Quality Function 
Deployment (QFD) Dan Athropometri," in Seminar Nasional Inovasi dan Aplikasi Teknologi di Industri, 2017, p. C47.1-5, available at: https://ejournal.itn.ac.id/index.php/seniati/ article/download/1044/745.

[14] A. Anugrahadi and $H$. Siringoringo, "Layout Evaluation and Redesign Using Simulation," International Seminar on Industrial Engineering and Management, 2008, pp. 28-35, available at: http://repository.gunadarma.ac.id/534/1/L ayout eveluation and redesign using simulation_UG.pdf.

[15] I. Pratiwi, E. Muslimah, and R. K. Setyojati, "Redesign of Equipment and Work Methods in Tofu Industries," in International Conference Proceeding; Narratives of Sustainable Development: Industry in the Global World Meeting Social Ecological Responsibility, 2011, available

at:

https://publikasiilmiah.ums.ac.id/xmlui/han dle/11617/9451.

[16] R. Setyowati, J. Jazuli, and R. Setyaningrum, "Penerapan Metode REBA dan EFD dalam Perancangan Stasiun Kerja Ergonomis pada Proses Pencetakan Produk Tahu," Appl. Ind. Eng. J., vol. 1, no. 2, pp. 65-75, 2017, available at: http://publikasi.dinus.ac.id/index.php/aiej/a rticle/view/1727.

[17] D. N. Izzhati, "Pengembangan alat pemotong tahu yang ergonomis dengan menggunakan metode RULA," Pros. SNST Fak. Tek., vol. 1, no. 1, pp. 7-11, 2010, available

at:

https://www.publikasiilmiah.unwahas.ac.id /index.php/PROSIDING_SNST_FT/article/ view/325.

[18] B. A. Haulian Siboro, V. M. Afma, A Purbasari, and M. Q. Kasim, "Design of Tofu Cutting Tools to Improve Repetitive Tasks Using OCRA," IOP Conf. Ser. Mater. Sci. Eng., vol. 528, no. 1, p. 012028, Jun. 2019, doi: 10.1088/1757899X/528/1/012028.

[19] M. Nugroho, N. Adi, and A. K. Al Ghofari, "Perancangan Alat Pemotong Tahu dengan Metode Benchmarking." Skripsi. Solo: Fakultas Teknik, Universitas Muhammadiyah Surakarta, 2018, available at: http://eprints.ums.ac.id/66752/.

[20] Widiyanti, F. Fadillah, A. W. Rahmawan, A. Sanusi, A. S. F. Narariya, and R. I. Andina, "Designing an automatic tofu pressing and molding machine for home industry," in 2017 5th International Conference on Electrical, Electronics and Information Engineering (ICEEIE), 2017, pp. 15-20, doi: 10.1109/ICEEIE.2017.8328755.

[21] G. K. Sidanta, W. Budiawan, and S. Sriyanto, "Redesain Alat Bantu Pres Tahu dengan Menggunakan Metode Quality Function Deployment (QFD) dan Teorija Rezhenija Izobretatelskih Zadach (Triz)(Studi Kasus: CV. Sumber Rejeki, Lampung)," Ind. Eng. Online J., vol. 5, no. 3, pp. 1-8, 2016, available at: https://ejournal3.undip.ac.id/index.php/ieoj /article/view/13095.

[22] M. Huang and X. Dong, "A Virtual Prototyping Technology for Design of Pressing Equipment of Dried Tofu," in International Conference on Computer and Computing Technologies in Agriculture, Springer, 2010, pp. 169-175, doi: 10.1007/978-3-642-12220-0 26.

[23] D. Budihamsyah and B. I. Putra, "Perbaikan Desain Alat Pemotong Tahu Dengan Pendekatan Rekayasa Nilai," Product. Optim. Manufactuiring Process, vol. 1, no. 2, pp. 123-135, 2017, doi: 10.21070/prozima.v1i2.1341.

[24] B. A. H. Siboro, M. F. . Siagian, and A. Purbasari, "Usulan Desain Proses Pengangkatan Sari Kedelai ke Penyaringan ( Studi Kasus Pabrik Tahu di Batam )," in Prosiding SNTI dan SATELIT, 2017, pp. B119-124, available at: https://docplayer.info/65965198-Usulandesain-proses-pengangkatan-sari-kedelaike-penyaringan-studi-kasus-pabrik-tahudi-batam.html.

[25] M. Siska, Y. Morena, and A. Anugrah, "Perancangan Alat Pengepresan dan Pemotongan Tabu yang Ergonomis (Studi Kasus: UD. Dika Putra)," in Industrial Engineering Conference on Telecommunication (INDECT), 2012, no. November, pp. 177-183, available at: https://repository.unri.ac.id/jspui/bitstream/ 123456789/5691/3/Abstrak.PDF.

[26] K. L. . Ulrich and S. D. Eppinger, Product Design and Development Management. New York: MCGraw-Hill Irwin, 2004, available at:: Google Scholar.

[27] S. S. Wijoyo, A. Santosa, and C. J. Pradjonggo, "Perancangan Furnitur dengan Material Kayu Balsa," Intra, vol. 6, no. 2, pp. 105-115, 2018, available at: http://publication.petra.ac.id/index.php/des ain-interior/article/view/7166. 